\section{Identification of occult metastases of medullary thyroid carcinoma by calcitonin measurement in washout fluid from fine needle aspiration of cervical lymph node}

\author{
Identificação de metástase oculta do carcinoma medular \\ de tireoide através da dosagem de calcitonina no lavado \\ da agulha de punção aspirativa de linfonodo cervical
}

Debora Siqueira ${ }^{1}$, Andreia Possati Rocha', Marcia Khaled Puñales ${ }^{1}$, Ana Luiza Maia ${ }^{1}$

\begin{abstract}
Medullary thyroid carcinoma (MTC) may occur sporadically or as a manifestation of an autosomal-dominant inherited syndrome, the multiple endocrine neoplasia type 2. DNA-based RET genotype analysis gained worldwide acceptance in the identification of asymptomatic gene carrier. MTC synthesize and secrete calcitonin, a well established tumor marker and postoperative level of serum calcitonin, indicates whether residual disease was left behind and whether reintervention is necessary. However, management is difficult when routine imaging studies for MTC are negative. This paper brings a report of an illustrative case of a patient with MTC diagnosed by molecular screening, who persisted with detectable levels of serum calcitonin after surgical procedure. After 48 months, an increase in serum calcitonin impelled us to investigate the disease focus. Cervical-US and calcitonin measurement in washout fluid from fine needle aspiration was successfully used to identify MCT metastasis in a lymph node, allowing appropriated reintervention and illustrating the potential clinical applicability of this method. Arq Bras Endocrinol Metab. 2009;53(4):479-81.
\end{abstract}

Keywords

Medullary thyroid carcinoma; calcitonin; diagnosis; metastasis

\section{RESUMO}

O carcinoma medular de tireoide (CMT) pode ocorrer na forma esporádica ou como manifestação da síndrome genética neoplasia endócrina múltipla tipo 2. Mutações de linhagem germinativa do proto-oncogene RET causam a forma hereditária, e o diagnóstico molecular é a base para o manejo adequado. O CMT sintetiza e secreta a calcitonina e os níveis séricos da calcitonina pós-tireoidectomia indicam se o paciente está curado ou se há necessidade de reintervenção. No entanto, o manejo é difícil quando exames de imagem são negativos. Neste estudo mostramos um caso ilustrativo de uma paciente com CMT hereditário diagnosticado por meio de rastreamento genético que persistiu com calcitonina sérica detectável pós-tireoidectomia. Após 48 meses, observou-se aumento da calcitonina sérica, determinando investigação para localizar o foco da doença. A utilização do US-cervical e a dosagem da calcitonina no lavado da agulha da punção aspirativa de linfonodo possibilitaram o diagnóstico e a reintervenção terapêutica, ilustrando a potencial aplicabilidade clínica desse método. Arq Bras Endocrinol Metab. 2009;53(4):479-81.

Descritores

Carcinoma medular de tireoide; calcitonina; diagnóstico; metástase
1 Thyroid Section, Endocrine Division, Hospital de Clínicas de Porto Alegre, Universidade Federal do Rio Grande do Sul, Porto Alegre, RS, Brazil
Correspondence to: Ana Luiza Maia Serviço de Endocrinologia, Hospital de Clínicas de Porto Alegre Rua Ramiro Barcelos, 2.350 90035-003 - Porto Alegre, RS, Brasil almaia@ufrgs.br

Received in Mar/1/2009 Accepted in Apr/6/2009 


\section{INTRODUCTION}

$\mathrm{M}$ edullary thyroid carcinoma (MTC) is a relatively rare disease, accounting for $3 \%$ to $5 \%$ of all thyroid malignancies. MTC may occur sporadically or as a manifestation of an autosomal-dominant inherited syndrome, the multiple endocrine neoplasia type 2 (MEN2), characterized by the presence of several endocrine tumors in variable clinical expression (1). Other features of MEN2A include pheochromocytoma (PHEO), and hyperparathyroidism (HPT). MEN2B presents a specific phenotype that encompasses lip, tongue and gastrointestinal tract neuromas, marfanoid habitus and/or skeletal anomalies. The RET proto-oncogene is the susceptibility gene for hereditary MTC (1).

A remarkable feature of MTC is the capability of synthesis and secretion of calcitonin, a well established tumor marker for this neoplasia (2). Surgery is the only effective treatment for patients with MTC, and the postoperative level of serum calcitonin will indicate whether residual disease was left behind or reintervention is necessary. However, management is difficult when routine imaging studies for MTC, such as cervical ultrasound (US), computed tomography, and magnetic resonance imaging (MRI), are negative due to elevated calcitonin or elevated carcinoembryonic antigen (CEA) tumor markers.

Lymph node metastases already occurred at the time of diagnosis on nearly $50 \%$ of MTC patients. In about two thirds of those patients, calcitonin levels remain elevated even after extensive surgery (3). Neck US is the most sensitive tool to detect lymph node metastases in patients with papillary thyroid carcinoma (PTC), and this also applies to MTC patients (4). Although fine needle aspiration biopsy (FNAB) of suspect lymph nodes is a value diagnostic tool for lymph node metastases, small or cystic lymph nodes may be nondiagnostic due to lack of tumor cells. The measurement of thyroglobulin (TG) levels in FNAB specimens from lymph nodes suspicious of recurrent PTC can serve as an adjunct to the cytologic diagnosis (5). Therefore, a similar approach could be used measuring calcitonin for diagnostic of lymph node MTC metastasis. In this context, a recent study evaluated the usefulness of calcitonin assay in FNA washout (6). This paper brings a report of a case in which this technique was successfully used to identify MCT metastasis in a small lymph node, illustrating the potential clinical applicability of this method.

\section{CASE REPORT}

Female, 30-years old, with hereditary MTC harboring a mutation RET codon 634 (C634R) diagnosed at 21 years old by molecular screening. At diagnosis, she presented a thyroid nodule $1.5 \times 1.0 \times 1.0 \mathrm{~cm}$ and her preoperative basal serum calcitonin level was $220 \mathrm{pg} / \mathrm{mL}$ (reference interval, $0-8 \mathrm{pg} / \mathrm{mL}$ ). She underwent a total thyroidectomy with lymph node dissection of levels III, IV and VI (bilaterally) in January, 2000. The pathological report confirmed $\mathrm{C}$ cell hyperplasia and multicentric MTC (larger nodule $1.5 \mathrm{~cm}$ ). No metastasis was found in 20 lymph nodes isolated. Since then, the patient has been followed according to the standard follow-up of hereditary MTC in our Division, that consists of determining basal serum calcitonin, plasma calcium and PTH (every six months) and abdominal computed tomography (CT, yearly). Six months later, her postoperative basal serum calcitonin dropped for $9 \mathrm{pg} / \mathrm{mL}$ and remained low, but still at detectable levels (Figure 1). After 48 months of follow-up, her basal serum calcitonin levels increased to $41 \mathrm{pg} / \mathrm{mL}$. Her physical examination was unremarkable and imaging studies (thorax and abdomen CT, and MRI) were negative. Cervical US identified a $0.8 \mathrm{~cm}$ lymph node in the internal right jugular chain. A USguided FNAB was performed for cytological examination and, after smear preparation, the needle was washed out with $500 \mu \mathrm{L}$ of saline and the solution processed for calcitonin measurement (Immulite, Diagnostic Product Corporation, Los Angeles, CA, USA; reference range for women, $<5 \mathrm{pg} / \mathrm{mL}$; detection limit, $<2.0$ ). The cytological report was inconclusive, whereas the calcitonin that was in FNAB fluid washout was $102,000 \mathrm{pg} / \mathrm{mL}$.

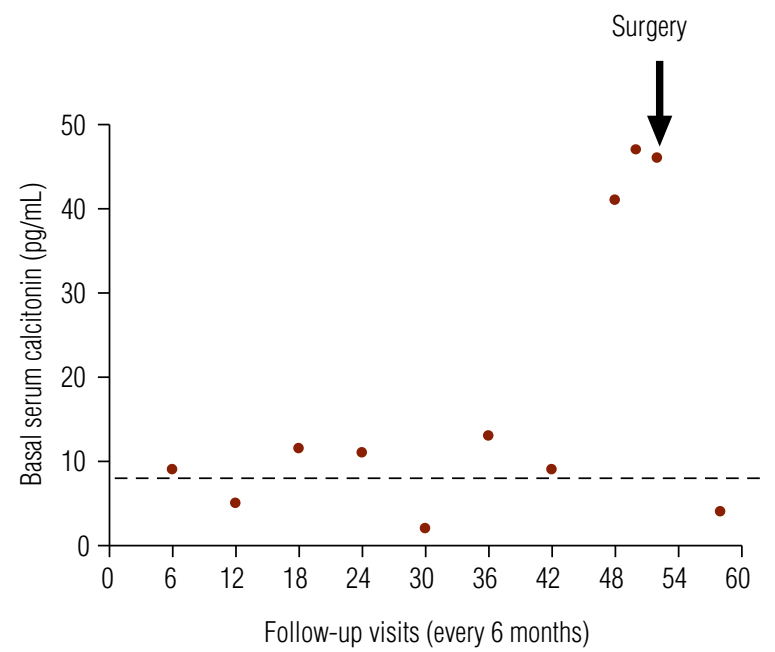

Figure 1. Basal serum calcitonin levels on follow-up visits after total thyroidectomy with lymph node dissection (0). Reference values are shown by the dash line. 
The patient underwent a cervical surgical intervention for lymph node dissection. The pathological report confirmed MTC metastases in two out of seven lymph nodes isolated from the right jugular carotid chain. No metastasis was found in 11 lymph nodes isolated from the left jugular chain. Six months later, her basal calcitonin was $4 \mathrm{pg} / \mathrm{mL}$.

\section{DISCUSSION}

The management of MTC patient with elevated calcitonin is particularly challenging in limited disease stages, when routine imaging studies often fail to identify affected organs. [18F]FDG-PET has recently been proposed to identify residual tumor masses (7). Nonetheless, this procedure also has limitations, as small tumors are rarely detected. It is also expensive and not readily available in most centers. The case herein reported illustrates two relevant aspects on follow-up of MTC patients. First, the presence of detectable levels of calcitonin after total thyroidectomy should alert for the risk of residual or persistent disease. Serum calcitonin levels will eventually increase and identification of occult metastases is, then, mandatory, although this is not always an easy task. In hereditary MTC, lymph node metastases occur in approximately $50 \%$ of cases and US-guided FNA biopsy seems to be the most accurate imaging modality to detect it (8-9). However, it should be noted that benign lymphadenopathies are extremely frequent and that unsatisfactory material is a common problem, especially in small lymph nodes, which occasionally results in unsuccessful surgical interventions. To circumvent these events, TG measurements in FNAB specimens from lymph nodes suspicious for recurrent PTC has been successfully used for the improvement of the diagnostic accuracy of lymph node metastasis $(5,10)$.

A recent study evaluated the usefulness of calcitonin assay in FNA washout and demonstrated that CT-FNA fluid washout has $100 \%$ of sensitivity and specificity for MTC, while cytology displayed only $61.9 \%$ of sensitivity and $80 \%$ of specificity (6). This case illustrates the potential clinical applicability of this method. It has been shown that US-guided CT-FNA measurement in fluid washout could be a valuable tool on detection of node metastasis. It is interesting to note that the calcitonin level in the FNAB fluid washout was over thousand times higher than the serum calcitonin level collected at the same time, thus excluding the possibility of contamination (Figure 1). Although in this particu- lar case the CT-FNA measurement has been performed in fluid washout from a cervical node, at least in theory, this could be use for diagnosing other suspected MTC metastatic lesions, avoiding unnecessary surgical procedures. This simple, inexpensive, and feasible diagnostic tool might be suggested as first line approach for identification of occult metastasis of MTC if these results are confirmed in a larger population of MTC patients who underwent total thyroidectomy, present increased serum calcitonin levels and no identified disease focus.

Acknowledgments: the authors would like to thank the financial support from Conselho Nacional de Desenvolvimento Científico e Tecnológico (CNPq), Fundação de Amparo à Pesquisa do Estado do Rio Grande do Sul (FAPERGS), and Fundo de Incentivo à Pesquisa (FIPE), Brazil.

Disclosure: no potential conflict of interest relevant to this article was reported.

\section{REFERENCES}

1. Lakhani VT, You YN, Wells SA. The multiple endocrine neoplasia syndromes. Annu Rev Med. 2007;58:253-65.

2. Costante G, Meringolo D, Durante $C$, Bianchi D, Nocera M, Tumino $S$, et al. Predictive value of serum calcitonin levels for preoperative diagnosis of medullary thyroid carcinoma in a cohort of 5817 consecutive patients with thyroid nodules. J Clin Endocrinol Metab. 2007;92(2):450-5.

3. Leboulleux S, Baudin E, Travagli J, Schlumberger M. Medullary thyroid carcinoma. Clin Endocrinol (Oxf). 2004;61:299-310.

4. Giraudet AL, Vanel D, Leboulleux S, Aupérin A, Dromain C, Chami $L$, et al. Imaging medullary thyroid carcinoma with persistent elevated calcitonin levels. J Clin Endocrinol Metab. 2007;92:4185-90.

5. Pacin F, Fugazzola L, Lippi F, Ceccarelli C, Centoni R, Miccoli P, et al. Detection of thyroglobulin in fine needle aspirates of nonthyroidal neck masses: a clue to the diagnosis of metastatic differentiated thyroid cancer. J Clin Endocrinol Metab. 1992;74(6):1401-4.

6. Boi F, Maurelli I, Pinna G, Atzeni F, Piga M, Lai ML, et al. Calcitonin measurement in wash-out fluid from fine needle aspiration of neck masses in patients with primary and metastatic medullary thyroid carcinoma. J Clin Endocrinol Metab. 2007;92(6):2115-8.

7. Gourgiotis L, Sarlis NJ, Reynolds JC, VanWaes C, Merino MJ, Pacak K. Localization of medullary thyroid carcinoma metastasis in a multiple endocrine neoplasia type $2 \mathrm{~A}$ patient by 6 -[18F]-fluorodopamine positron emission tomography. J Clin Endocrinol Metab. 2003;88:637-41.

8. Scollo C, Baudin E, Travagli JP, Caillou B, Bellon N, Leboulleux S, et al. Rationale for central and bilateral lymph node dissection in sporadic and hereditary medullary thyroid cancer. J Clin Endocrinol Metab. 2003;88(5):2070-5.

9. de Bondt RB, Nelemans PJ, Hofman PA, Casselman JW, Kremer $B$, van Engelshoven JM, et al. Detection of lymph node metastases in head and neck cancer: a meta-analysis comparing US, USgFNAC, CT and MR imaging. Eur J Radiol. 2007;64:266-72.

10. Biscolla RP, Ikejiri ES, Mamone MC, Nakabashi CC, Andrade VP, KasamatsuTS, et al. Diagnosis of metastases in patients with papillary thyroid cancer by the measurement of thyroglobulin in fine needle aspirate. Arq Bras Endocrinol Metab. 2007;51(3):419-25. 